\title{
PHYSICAL ACTIVITY ROUTINE BY PHYSICAL ACTIVITIES RELATED TO BODY MASS INDEX
}

\author{
Isna Daniyati Nursasih ${ }^{1}$, Hendra Rustiawan ${ }^{1}$, Andang Rohendi ${ }^{1}$, Syifa Nurbait ${ }^{2}$, Siskha \\ Noor Komala ${ }^{3}$
}

${ }^{1}$ Physical Education, Faculty of Teacher Training and Education, Universitas Galuh, Ciamis, Indonesia

${ }^{2}$ Physical Education, Health and Recreation, Faculty of Teacher Training and Education, Universitas Nahdlatul Ulama Cirebon, Cirebon, Indonesia

${ }^{3}$ Health Analyst, Stikes Bakti Tunas Husada, Tasikmalaya, Indonesia

\begin{tabular}{l} 
Article Info \\
\hline Article History: \\
Received August 2020 \\
Revised August 2020 \\
Accepted August 2020 \\
Available online September 2020 \\
\hline Keywords: \\
Routines, physical activity, body \\
mass index
\end{tabular}

\section{Abstract}

This study aims to find out relations of college student habbit on the physical education in sport activity with his body mass index. Physical activity are usually done by everyone, as well as college student at physical education. It is familiar. This study was conducted at a time, in 36 students who were all male sex with the age range of 20-24 years old. To known the result from the data will be processed, researchers used an instrument of the questionnaire. The questionnaire was immediately filled by each respondent without given any treatment previously. Category was obtained from the measurement of body mass index between height and weight each respondent. There is only one group in this research, no groups were compared. The method used is quantitative and data analysis using the technique chi square. The data obtained were then processed with SPSS 21 series. After data processed, the results show there is a significant correlation between both variables. 


\section{INTRODUCTION}

Doing physical activity is a necessity for every individual. Moving is one of the living things characteristics. For moving, humans need energy for muscle contraction, it can be obtained from food consumed (Komariyah, Sucipto \& Kurnia, 2013). Every living thing moves to support its activities in daily life. The fulfillment needs of each individual is different, depending on whether the physical activity by heavy. The calories needed are adjusted to the activities carried out daily. In addition, gender and age also provide differences from individual daily calorie needs.

At this time technology is experiencing tremendous development. Advancement of internet technology facilitates electronic commerce activities that have changed the behavior of consumers and service providers (Suhartanto, Helmi Ali, Tan, Sjahroeddin, \& Kusdibyo, 2019). The public is spoiled by the many conveniences provided by electronic services. You don't need to go far to get the items or food you need. Many physical activities have begun to be shifted in function made easier by the development of this technology.

Currently, services available in various forms of applications and types are offered that provide many conveniences for the community in meeting their daily needs. The availability of online technology allows customers to order food through restaurant websites or through online food delivery services such as Eat24, GrabFood, and GoFood (Suseno, Salim, \& Setiadi, 2017). This allows a decrease in physical activity in community.

For people who are aware of fulfilling their mobile needs, they'll take the time to do physical activities. Physical activity can be done in various activities, for example by exercising regularly. Routine exercise can reduce the obesity risk because the movement need is fulfilled. For teenagers, involvement in sports can be done in sports clubs or in extracurricular activities (Nursasih, Ma'mun, Mahendra, Risma, \& Rohmanasari, 2019). In addition, at all education level in schools physical education lessons are given as a form of government effort to meet the needs of each individual's movement. Activities carried out in physical education can improve abilities in the cognitive realm, increase in learning abilities, as well as improve health (Chen et al., 2019).

Being overweight and obese refers to condition of body weight and its relationship to height (Katzmarzyk et al., 2008). In fact, being able to lose weight is not easy and a tremendous challenge (Mozaffarian, Hao, Rimm, Willett, \& Hu, 2011). To be able to lose weight, it's necessary to pay attention to the intake of nutrients consumed. If you look at excess weight that occurs, this can be used as evidence of a lifestyle that's lived, including a lack of exercise, making it more susceptible to obesity (Hansen, Landstad, Gundersen, \& Svebak, 2012). Regular exercise cann't help losing weight, but can also strengthen muscles and bones (Dimitriou, Michalopoulou, Gourgoulis, \& Aggelousis, 2011).

Fitness according to recent research is considered an important trait in the health of children and adolescents (Cadenas-Sanchez et al., 2020). Although body fat percentage has nothing to do with the level of physical fitness (Rohendi et al., 2020), sport activity still provide benefits that can be felt in psychological and social relationships terms with other individuals (Mannino et al., 2019). 
Everyone needs a certain amount of body fat which is useful for storing energy, as a heat insulation, resistance from shock to organs and other body functions (Husnah, 2012). Balancing the calories consumed with calories used will help the body stay ideal. Whether a person's body is normal or not can be known from his body mass index. Apart from sports activities, body mass index is highly correlated with the level of knowledge (Ho et al., 2011). Therefore, in this study, we wanted to know the relationship between exercise routine and body mass index.

\section{METHODS}

The method used is quantitative, with a correlation design that connects the two research variables. There is no additional treatment or manipulation, only once taking the data.

\section{Participants}

Respondents of this study were male students majoring in Physical Education level 3, class employees at the FKIP Galuh University.

\section{Sampling Procedures}

Respondents were taken by total sampling method, from class 3 employees with an age range of 20-24 years. Respondents amounted to 36 people. Filling in this instrument is carried out at the Galuh Ciamis University campus environment.

\section{Materials and Apparatus}

Research instrument used was a questionnaire. This instrument contains questions about weight, height as well as habits in sports activities. To find out the body mass index, the standard formula from WHO is used.

\section{Procedures}

Sports is an activity that is usually carried out by students majoring in physical education during lectures. In fact, there is a lot of time that can be used by each student outside of this time to exercise according to their respective talents and interests. For the 3rd level students who were used as respondents, they taught badminton courses, with this at least the respondents did exercise once a week.

No groups were compared, the respondents only filled in each item posed. Therefore, it was enough to hold 2 meetings. The first meeting discussed the variables to be studied and the second meeting was for data collection.

\section{Design or Data Analysis}

Data generated will useless when it's not followed by a calculation. The results of this data are quantitative and calculated using the help of the SPSS formula version 21 , namely the frequency distribution and chi square. All variables in the questionnaire are discussed one by one so that the expected results can be seen clearly.

\section{RESULT}

This section describes the research results that has been done. In this case, exercise routine becomes variable (x) and body mass index as variable (y). The questionnaire used intends to reveal the routines carried out by the respondents in which it also discusses what sports are carried out, time of implementation and frequency of sports activities.

\section{Tables and Figures}

Tables are presented in a simple form so that they are easy to understand. The following are the results of each analysis carried out for each item on the research questionnaire. 
Table 1. The Routines Sports Activity

\begin{tabular}{ccccc}
\hline & $\begin{array}{c}\text { Frequen } \\
\text { cy }\end{array}$ & $\begin{array}{c}\text { Perce } \\
\text { nt }\end{array}$ & $\begin{array}{c}\text { Valid } \\
\text { Percen } \\
\text { t }\end{array}$ & $\begin{array}{c}\text { Cumulat } \\
\text { ive } \\
\text { Percent }\end{array}$ \\
\hline No & 11 & 30.6 & 30.6 & 30.6 \\
\hline Yes & 25 & 69.4 & 69.4 & 100.0 \\
\hline Total & 36 & 100.0 & 100.0 & \\
\hline
\end{tabular}

Table 2. Sports That are Routinely Carried Out

\begin{tabular}{|c|c|c|c|c|}
\hline & $\begin{array}{c}\text { Freque } \\
\text { ncy }\end{array}$ & $\begin{array}{c}\text { Perce } \\
\text { nt }\end{array}$ & $\begin{array}{c}\text { Valid } \\
\text { Perce } \\
\text { nt }\end{array}$ & $\begin{array}{l}\text { Cumula } \\
\text { tive } \\
\text { Percent }\end{array}$ \\
\hline Never & 11 & 30.6 & 30.6 & 30.6 \\
\hline $\begin{array}{l}\text { Big ball } \\
\text { game }\end{array}$ & 20 & 55.6 & 55.6 & 86.1 \\
\hline $\begin{array}{c}\text { Small } \\
\text { ball } \\
\text { game }\end{array}$ & 1 & 2.8 & 2.8 & 88.9 \\
\hline $\begin{array}{c}\text { Self- } \\
\text { defense }\end{array}$ & 2 & 5,6 & 5,6 & 94.4 \\
\hline Athletics & 1 & 2.8 & 2.8 & 97.2 \\
\hline Others & 1 & 2.8 & 2.8 & 100.0 \\
\hline Total & 36 & 100.0 & 100.0 & \\
\hline
\end{tabular}

Table 3. Time of Sport Acitvity

\begin{tabular}{|c|c|c|c|c|}
\hline & $\begin{array}{c}\text { Frequen } \\
\text { cy }\end{array}$ & $\begin{array}{c}\text { Perce } \\
\text { nt }\end{array}$ & $\begin{array}{c}\text { Valid } \\
\text { Perce } \\
\text { nt }\end{array}$ & $\begin{array}{c}\text { Cumula } \\
\text { tive } \\
\text { Percent }\end{array}$ \\
\hline Never & 11 & 30.6 & 30.6 & 30.6 \\
\hline $\begin{array}{c}\text { Mornin } \\
\mathrm{g}\end{array}$ & 7 & 19.4 & 19.4 & 50.0 \\
\hline $\begin{array}{c}\text { Daytim } \\
\mathrm{e}\end{array}$ & 1 & 2.8 & 2.8 & 52.8 \\
\hline $\begin{array}{c}\text { Afterno } \\
\text { on }\end{array}$ & 16 & 44.4 & 44.4 & 97.2 \\
\hline $\begin{array}{l}\text { Evenin } \\
\mathrm{g}\end{array}$ & 1 & 2.8 & 2.8 & 100.0 \\
\hline Total & 36 & 100.0 & 100.0 & \\
\hline
\end{tabular}

Table 4. Frequency of Sport Acivity

\begin{tabular}{|c|c|c|c|c|}
\hline & $\begin{array}{c}\text { Frequen } \\
\text { cy }\end{array}$ & $\begin{array}{c}\text { Perce } \\
\text { nt }\end{array}$ & $\begin{array}{c}\text { Valid } \\
\text { Perce } \\
\text { nt }\end{array}$ & $\begin{array}{c}\text { Cumula } \\
\text { tive } \\
\text { Percent }\end{array}$ \\
\hline Never & 11 & 30.6 & 30.6 & 30.6 \\
\hline 1 time & 4 & 11.1 & 11.1 & 41.7 \\
\hline 2 times & 4 & 11.1 & 11.1 & 41.7 \\
\hline 3 times & 7 & 19.4 & 19.4 & 52.8 \\
\hline $\begin{array}{c}\text { More } \\
\text { than } \\
3 \text { times }\end{array}$ & 10 & 27.8 & 27.8 & 72.2 \\
\hline Total & 36 & 100.0 & 100.0 & 100.0 \\
\hline
\end{tabular}

Table 5. Body Mass Index

\begin{tabular}{lcccc}
\hline & \multicolumn{4}{c}{ Valid Cumula } \\
& $\begin{array}{c}\text { Frequen Perc Percen } \\
\text { cy }\end{array}$ & ent & $\mathrm{t}$ & Percent \\
\hline Underweig & 4 & $\begin{array}{c}11 . \\
\text { ht }\end{array}$ & 11.1 & 11.1 \\
\hline Normal & 30 & $\begin{array}{c}83 . \\
\text { Overweight }\end{array}$ & 83.3 & 94.4 \\
\hline Overweing & 1 & 2.8 & 2.8 & 97.2 \\
\hline Obese & 1 & 2.8 & 2.8 & 100.0 \\
\hline \multicolumn{1}{c}{ Total } & 36 & 100 & 100.0 & \\
& & .0 & & \\
\hline
\end{tabular}

Table 6. Crosstabulation

Exercise Routines $(\mathrm{X}) *$ Body Mass Index (Y)

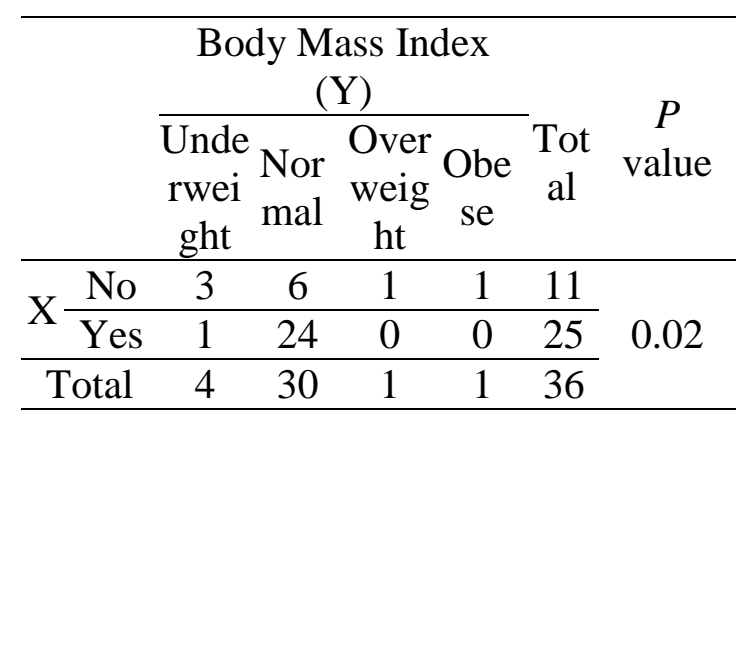


Table 7. Percentage of Crosstabulation Results

Body Mass Index (Y)

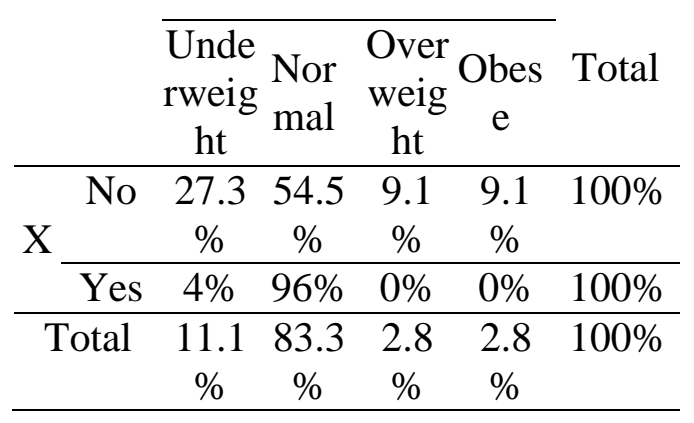

\section{DISCUSSION}

There are 7 tables that the researcher will describe, as a data analysis result that has been carried out. The first in table 1 discusses the routine in doing sports activities, here it can be seen that not all respondents do it regularly. It can be seen in table 1 of the respondents total number, there are 11 people who don't do sports regularly. Therefore, in the next table the number of respondents who do not carry out routine activities will remain the same, namely 11 people.

There are many sports that can be done by the community. In this study, researchers divided the sport into at least 5 types of sports. It can be seen in table 2 starting from the selected sport there is volleyball, basketball, and soccer. According to the data it obtained are the most popular sports. Other sport selected include table tennis, tennis and badminton. Martial Arts, Judo, and Karate which are included in martial arts and athletic sports. For respondents who didn't choose the sports provided, other options were given. Similar to athletics and small ball games, there is 1 person who chooses others.

Sports can be done at any time according to other activities that are routinely carried out on a daily basis. Looking at the calculation results in table 3 , most of the respondents did it in the afternoon, as many as 16 people. Only 1 person does it during the day and at night. The frequency of doing sports activities is different for each respondent. 10 people do it more than 3 times a week. So, although in table 1 it is described that there are 25 people who routinely do it in a week in table 4, this is explained in more detail for the frequency.

Body balance has a good effect on body mass index. Nutritional intake, sports activities as well as spiritual health such as a good mood to control the activities carried out by the body. All these things can help balance the body. Because if there is an imbalance it will have a negative impact, one of which is the disruption of the body's metabolic system. Weight gain will occur if the body's metabolic system is slow (Puspitawati, 2019). A total of $83.30 \%$ of the respondents in this study have an normal body weight (table 5), as is the body mass index category for Indonesia (Republic of Indonesia Health Ministry, 2019).

Based on table 6, it's known that of the 11 respondents who didn't regularly exercise, most of them had an normal body weight of 6 people or $54.5 \%$. Likewise, almost all of those who routinely do sports activities, namely as many as 24 people or $96 \%$ have an normal body weight. The significance value shows that the number 0.02 is smaller than 0.05 . This figure shows that routine exercise has a relationship with body mass index. For further research, we can explore more about the afternoon time which is the most preferred choice in this study for sports activities, because this study only discusses the selection without knowing the reasons for choosing the time. 


\section{CONCLUSION}

Based on calculating results of body mass index by formula previously mentioned, most of the respondents are in normal body weight category. After looking at data from the questionnaire, it turns out that some people who have not normal body weight do not regularly exercise. Apart from the many factors that support the achievement of an normal body weight, it can be concluded that there is a relationship between routine physical activities, which in this case is doing sports with body mass index.

\section{ACKNOWLEDGEMENT}

The researcher would like to thank the entire academic community in the Physical Education Study Program, FKIP Galuh University. To all male students of grade 3 class 2016 employees who have been willing to take the time to fill out the questionnaire that the researcher gave so that this research can run smoothly.

\section{REFERENCES}

Cadenas-Sanchez, C., Migueles, J. H., Esteban-Cornejo, I., Mora-Gonzalez, J., Henriksson, P., RodriguezAyllon, M., ... Ortega, F. B. (2020). Fitness, physical activity and academic achievement in overweight/obese children. Journal of Sports Sciences, O(0), 1-10. https://doi.org/10.1080/02640414.20 20.1729516

Chen, B. H., Michael, S., Borgogna, B., Holmes, K., Hughes, K., Jew, L., \& Juergens, M. (2019). Integrate Classroom Physical Activity in Schools. Journal of Physical Education, Recreation and Dance, 90(8), $10-19$. https://doi.org/10.1080/07303084.20 19.1649577

Dimitriou, M., Mchalopoulou, M.,
Gourgoulis, V., \& Aggelousis, N. (2011). Participation in communitybased sport skills learning programmes, physical activity recommendations and health-related fitness for children in Greece. Sport Sciences for Health, 6(2-3), 93-102. https://doi.org/10.1007/s11332-0110103-4

Hansen, E., Landstad, B. J., Gundersen, K. T., \& Svebak, S. (2012). The relative importance of aerobic capacity, physical activity and body mass index in impaired glucose tolerance and Type 2 diabetes. Vulnerable Groups \& Inclusion, 3(1), 10232. https://doi.org/10.3402/vgi.v3i0.102 32

Ho, A. J., Raji, C. A., Becker, J. T., Lopez, O. L., Kuller, L. H., Hua, X., ... Thompson, P. M. (2011). The Effects of Physical Activity, Education , and Body Mass Index on the Aging Brain, 1382, 1371-1382. https://doi.org/10.1002/hbm.21113

Husnah. (2012). Tatalaksana Obesitas. Jurnal Kedokteran Syiah Kuala, 12(2), 99-104.

Katzmarzyk, P. T., Baur, L. A., Blair, S. N., Lambert, E. V., Oppert, J. M., \& Riddoch, C. (2008). International conference on physical activity and obesity in children: Summary statement and recommendations. International Journal of Pediatric Obesity, 3(1), 3-21. https://doi.org/10.1080/1747716070 1789679

Kementrian Kesehatan Republik Indonesia. (2019). Pengertian Kementrian Kesehatan Republik Indonesia. Retrieved from https://id.wikipedia.org/wiki/Kemen terian_Kesehatan_Republik_Indones ia

Komariyah, L., Sucipto, \& Kurnia. (2013). Ilmu Gizi Olahraga. https://doi.org/10.1558/jsrnc.v4il.24 
Mannino, G., Giunta, S., Montefiori, V., Tamanza, G., Iacolino, C., Novara, C., ... Bernardone, A. (2019). Healthy Lifestyle, Well-being, Physical Activity, Sport, and Scholastic/academic Performance: Interactions and Connections. World Futures, 75(7), 462-479. https://doi.org/10.1080/02604027.20 19.1654772

Mozaffarian, D., Hao, T., Rimm, E. B., Willett, W. C., \& Hu, F. B. (2011). Changes in diet and lifestyle and long-term weight gain in women and men. New England Journal of Medicine, 364(25), 2392-2404. https://doi.org/10.1056/NEJMoa101 4296

Nursasih, I. D., Ma'mun, A., Mahendra, A., Risma, R., \& Rohmanasari, R. (2019). Integrating Life Skills into Sport Club Activity, 11(Icsshpe 2018), 104-106. https://doi.org/10.2991/icsshpe18.2019.29

Puspitawati, I. D. (2019). Perilaku Aktivitas Olahraga Pada Saat Bulan Ramadhan. Jurnal Ilmu Keolahragaan, 2(2), 30. https://doi.org/10.26418/jilo.v2i2.35 328

Rohendi, A., Rustiawan, H., Maryati, S., Studi, P., Jasmani, P., \& Galuh, U. (2020). Hubungan Persentase Lemak Tubuh Terhadap Tingkat Kebugaran Jasmani, 7(1), 1-8. Retrieved from http://dx.doi.org/10.25157/wa.v7i1.3 068

Suhartanto, D., Helmi Ali, M., Tan, K. H., Sjahroeddin, F., \& Kusdibyo, L. (2019). Loyalty toward online food delivery service: the role of e-service quality and food quality. Journal of Foodservice Business Research, 22(1), 81-97. https://doi.org/10.1080/15378020.20 18.1546076
Suseno, Y., Salim, L., \& Setiadi, P. (2017). Local contexts and organizational learning for innovation in an emerging economy: the case of two Malaysian firms in Indonesia. Asia Pacific Business Review, 23(4), 509-540. https://doi.org/10.1080/13602381.20 17.1346906 